\section{Англійська \\ мова}

English

language
ISSN: 2411-6181(on-line); ISSN: 2311-9896 (print)

Current issues of social studies and history of medicine. Joint

Ukrainian-Romanian scientific journal, 2017, №:1(13), P. 69-73

UDK 811.161.2'373.46:61

DOI 10.24061/2411-6181.1.2017.16

ПЕРЕХІД ЕПОНІМІВ ГАЛУЗІ МЕДИЦИНИ В

ЗАГАЛЬНІ СЛОВА

АнНа ШАЛАСВА, Ірина СЕМЕНКО, Інна ТОМКА,

ВДНЗ України «Буковинський державний

медичний університет», Чернівці (Україна)

Lada_verina@mail.ru, irina2015@yandex.ru,

itomka@mail.ru

\title{
TRANSFORMATION OF EPONYMS IN THE FIELD OF \\ MEDICINE INTO COMMON WORDS
}

Anna SHALAJEVA, Iryna SEMENKO, Inna TOMKA,

Higher State Educational Establishment of Ukraine

„Bukovinian State Medical University“, Chernivtsi (Ukraine)

ORCID ID: 0000-0002-3356-721X

ORCID ID: 0000-0001-5035-7524

ORCID ID: 0000-0001-7123-9375

Шалаева Анна, Семенко Ирина, Томка Инна. Переход эпонимов сферы медицины в имена нарицательные. Актуальность данной статьи обусловлена широким вниманием к употреблению эпонимических терминов в различных областях науки и в частности в области медицины.

Целью данного исследования было определение причин широкого употребления эпонимических терминов в подъязыке медицины, исследование специфики медицинской эпонимической терминологии, выявление различных точек зрения на связь между общепринятыми медицинскими терминами и терминами-эпонимами, проведение анализа отличий медицинских эпонимов от общеупотребительных терминологических единиц, выявление сфер употребления эпонимической терминологической лексики и исследование перехода эпонимических терминов в имена нарицательные. Был проведен анализ типов эпонимов, которые могут переходить в имена нарицательные; какие функции такого типа имена нарицательные утрачивают и для обозначения каких лингвистических категорий они употребляются. Дальнейшие исследования перехода эпонимических терминов в имена нарицательные могут быть связаны с использованием и дальнейшей разработкой классификации имен нарицательных, производных от эпонимических терминов.

Ключевые слова: имена собственные, нарииательные имена, эпонимические термины, медииина, трансформаиия.

Актуальність статті полягає в тому, що в останні десятиліття стрімкий розвиток нових напрямків в галузі науки вимагає посиленої уваги мовознавців як до визначення поняття епонімічного терміну, так і до дослідження шляхів переходу епонімів в загальні слова.

Питання, пов’язані з проблемами власних та загальних імен з погляду їх словотвору, структури, семантики, взаємозв'язку, вживання та значення вже вивчалися такими вітчизняними і зарубіжними лінгвістами як Суперанська О.В., Блейхер В.М., Щерба Л.В., Новінська Н.В., Кондрат'єва Т.Н., Калмазова Н.А., Ізвєкова Т.Ф., Кондрат'єв Д.К., Смірнова С.В., Чернова Н.А. та ін. Точки зору лінгвістів стосовно питання про семантику власного імені значно відрізняються. Одні дослідники вважають, що власні імена не мають лексичного значення и не пов'язані з поняттями (А. А. Реформатський, Н. Д. Арутюнова, С. Д. Шеллов, С. Ульман, А. Бах та ін.). Інші, навпаки, вважають, що власні імена володіють значенням та являють собою одну 3 найбільш змістових категорій (Л. В. Щерба, В. А. Ніконов, С.В. Гриньов, О. Есперсен, К. Хенгст та ін.). О. В. Суперанська заперечує прямий, безпосередній в'язок власних імен 3 поняттями, співвідносить їх 3 поняттями тих загальних слів, якими можуть бути позначені об'єкти, що позначаються.

Проте й надалі багато питань, пов' язаних з власними та загальними словами, а тим більше 3 епонімічними термінами, залишаються остаточ-но нез'ясованими i привертають увагу лінгвістів. Досі триває дискусія стосовно доцільності вживання епонімічних термінів в наукових сферах і в галузі медицини зокрема.

Мета статті - дослідити шляхи та способи переходу епонімічних медичних термінів в загальні слова. Головним завданням $\epsilon$ спроба класифікації значень загальних слів, що утворилися шляхом переходу із власних імен.

За ознакою називання предмету як індивідуального або як представника цілого класу всі іменники поділяються на власні (оніми) та загальні. Складно сказати, які іменники переважають в мові - власні чи загальні.

Загальний іменник - слово, що називає предмет за його належністю до одного чи іншого класу. Такі слова $\epsilon$ узагальненим найменуванням однорідних предметів. Ім'я загальне може позначати не тільки категорію предметів, а й будь-який окремий предмет всередині цієї категорії.

Власне ім'я - це таке слово, яке означає індивідуальну назву одного з ряду однотипних предметів чи взагалі одного існуючого і виконує ідентифікаційну функцію. Лінгвістичний розділ, що займається вивченням власних імен, їх історією та закономірностями їх виникнення, їх функціонуванням, змінами та структурою, називається ономастикою. Термін ономастика походить від грецького onomakypia - власне ім'я. Епонім це ім'я людини, реальної чи вигаданої, на основі якого 
створене інше слово чи словосполучення ${ }^{1}$.

Незважаючи на існування розбіжностей в поглядах на роль епонімічних термінів в різних галузях науки, всі дослідники погоджуються 3 можливістю переходу мовної одиниці 3 одного розряду в інший. А.В. Суперанська відмічає, що „Беззаперечною умовою будь-якого (повного чи часткового, ситуативного) переходу власного імені в загальне слово $\epsilon$ те, що денотат повинен бути відомим“².

Існують дві точки зору на зв'язок власних та загальних найменувань:

- розмежування між власними та загальними іменами не абсолютне (Л.А. Булаховський, В.А. Ніконов);

- це розмежування абсолютне, тому що ніяких «проміжних явищ між власними та загальними іменами не існує» (Ю. А. Карпенко).

Проміжними словами, тобто такими, що знаходяться між власними та загальними найменуваннями, лінгвісти вважають етноніми (найменування націй, народів, народностей, племен i т.і.). Одні дослідники мови відносять їх до ономастики, інші - до апелятивної лексики.

Мовні дослідження авторів статті проводились 3 епонімічними термінами галузі медицини, пов'язаної з практичною діяльністю медиків. В цьому плані розглядалися терміни-епоніми, що описували хвороби, ïх симптоми, синдроми; тести на виявлення хвороб, практичний інструментарій. Вивчалися шляхи переходу епонімічних термінів в загальні слова (деонімізація, суфіксація). Дослідження проводились на базі словникового матеріалу ілюстрованого медичного словника Дорланда та інших медичних словників.

Мова медицини - це специфічна мова. Власні імена як терміни в галузі медицини використовуються тільки спеціалістами в певній сфері медицини як терміни, зрозумілі в основному тільки їм. Їх вживання потребує певного рівня наукової освіти. Пояснити їх походження неможливо, тому що вони не відображають будь-якої основної, суттєвої характеристики терміну. Вони не інформують тих, хто їх вживає про вміст та основне значення терміну. Немає спеціального підрозділу лінгвістики, що вивчає медичну мову. Велика частина медичної термінології представлена епонімами i епонімічні терміни в медицині вивчені набагато більше ніж в інших мовних підрозділах. Епонім (грец. eponymos, epi «після» + onoma «ім’я») = «той, що дає своє ім'я». Таких термінів в галузі медицини дуже багато. Частіше всього вони вживаються для позначення хвороб на честь лікаря, який вперше описав стан хворої людини (Charcot's disease - хвороба Шарко, нейропатична артропатія, вперше описана в 1869 році Жан-Мартеном Шарко), або хворобі надане ім'я людини, яка страждала від цієї хвороби (Hagner disease
- гіпертрофічна остеоартропатія).

Якщо епонім вживається для позначення хвороби, то найчастіше він вживається для описання симптому, синдрому, фактору, тесту, аномалії, яким надається ім'я на честь лікаря-винахідника.

Епонімічні терміни не зовсім нове явище в медицині. Вони були відомі ще в часи Галена (приблизно 2-ге століття до нашої ери). Більш широке вживання почалося в 1-й половині 19 століття. Відомо, що найбільша кількість епонімів існує в ревматології та неврології, але перші епоніми з'явилися в анатомії. Найчастіше епоніми виникають не в результаті наукового узагальнення, дослідження чи міжособистого спілкування, а як результат практичної діяльності медиків. Як результат роботи гастроентерологів виникли такі епоніми як Balint's diet - дієта Балінта, дієта для хворих епілепсією; Giovanetti's diet - дієта Джованетті, низькобілкова дієта; Meulengracht's diet дієта Мейленграхта, дієта для хворих на виразку шлунку, ускладненою кровотечею; в результаті хірургічної практики з'явилися назви хірургіних інструментів: Miculicz clamp - зажим Микуліча, Kocher's clamp - зажим Koxepa, Luer's forcepts - зажим Люера, Pean's forcepts - зажим Пеана, Hartmann's forcepts - зажим Хартманна, Halstead's forcepts - зажим Холстеда; як результат практичної діяльності в галузі урології з'явилися епонімічні терміни: Zimnitsky's test проба Зімницького, Howard's test - тест Говарда, Volhard's test - проба Фольгарда ${ }^{3}$.

Таким чином, медичні епоніми увічнюють внесок певних медиків-практиків в розвиток медичної науки i практики. Епоніми - це найвищий ступінь визнання лікаря в науці. Деякі вчені зробили дуже великий внесок в розвиток медичної науки. Важко переоцінити внесок німецького мікробіолога Р. Коха (Heinrich Hermann Robert Koch, 1843-1910) в розвиток бактеріології та епідеміології. На його честь 3'явилися такі епонімічні терміни як Koch's tuberculin - туберкулін Коха, Koch's bacillus - палочка Коха (tubercle bacillus). Епонімічні терміни виникають під час опису складних, неоднозначних явищ в тих галузях медицини, в яких практична діяльність часто передує науковим дослідженням та класифікації ${ }^{4}$.

В галузі медицини імена вчених та лікарів-практиків, які першими надали опис або відкрили певне медичне явище складають найбільшу по кількості групу. В епонімічній термінології увічнені імена понад 6 тисяч лікарів і вчених, які представляють більш ніж 60 країн світу ${ }^{5}$. Не дивлячись на пропозиції деяких вчених (зокрема Д.С. Лотте) обмежити вживання епонімічних термінів, бажання зберегти ім'я вченого для нащадків призводить до широкого розповсюдження епонімів в різних галузях науки ${ }^{6}$. Це пояснюється тим, що спеціалістам галузі медицини та тим, хто використовує

\footnotetext{
${ }^{1}$ Smirnova E.V. Strukturnye osobennosti obrazovanija jeponimov v medicinskoj terminologii (na primere anglijskogo jazyka) [Structural Peculiarities of the Formation of Eponyms in Medical Terminology (on the Pattern of the English language)], URL: https://www.isuct.ru/e -pub1/vgf/sites/ru.e-publ.vgf/files/2014/vgf-2014-06-100.pdf

${ }^{2}$ Superanskaja A.V. Obshhaja teorija imeni sobstvennogo [Genaral Theory of a Personal Name], M: Nauka, 1973, P. 117.

${ }^{3}$ Petrov V.I. Russko-anglijskij medicinskij slovar'-razgovornik [Russian-English Medical Phrase-book], M.: Rus. jaz., 1993 , P. 165.

${ }^{4}$ Chernova N.A. "Otymennye terminy v medicinskoj terminologii” [Denominative Terms in Medical Terminology], Zhurnal Bjulleten' medicinskih internet-konferencij, Vyp. № 1, T. 3 (2013), P. 1254, URL: http://cyberleninka.ru/article/n/otymennye-terminy-v- meditsinskoy-terminologii

${ }^{5}$ Kondrat'ev D.K. Sovremennaja medicinskaja jeponimicheskaja terminologija, [Modern Medical Eponymic Terminology], S.129. URL: https: cyberleninka.ru/article/n/sovremennaya-meditsinskaya-eponimicheskaya- terminologiya

${ }^{6}$ Izvekova T.F., Grishhenko E.V., Purtov A.S. Jeponimy v medicinskoj terminologii [Eponyms in Medical Terminology], P. 3, URL: https: ngmu.ru/cozo/mos/article/text_full.php?id=1365
} 
медичну лексику, цікаво знати, хто відкрив, вивчив або хто першим почав лікувати те чи інше захворювання людини і на чию честь названі хвороби, симптоми, синдроми чи тести, хто першим винайшов медичні інструменти чи прилади.

Мова живе життям того покоління, при якому вона існує. Змінюються покоління і змінюється мова. Власні імена переходять в загальні слова, загальні слова стають власними, існують періоди, коли навіть не можна визначити до якої категорії належить те чи інше слово ${ }^{7}$.

Мова галузі медицини також підкоряється законам загальної мови, яка являє собою рухоме утворення, чиї одиниці мають властивість переходу з однієї підсистеми в іншу. Процеси перетворення власних імен в загальні назви відбуваються і в медичній термінології. Дане явище назване «апелятивація», при якій власна назва втрачає ряд притаманних йому в мові властивостей, які стають несуттєвими, і починає вживатися в якості загальної назви.

Власні імена набувають функцію узагальнення, втрачають індивідуальні ознаки і власну предметну віднесеність. 3 часом такі слова вже не сприймаються як такі, що утворилися від антропонімів, втрачається їх зв'язок 3 власним ім'ям. Таким чином епонімічні терміни суттєво збагачують лексичний склад професійної медичної мови. Різниця між власними іменами і загальними іменниками непостійна і рухлива: імена загальні легко стають власними найменуваннями, а власні імена часто використовуються для узагальненого позначення однорідних предметів і стають при цьому загальними. Більш того, 3 переходом власного імені в розряд загальних слів, відбувається поступове набуття ним понятійності ${ }^{8}$. Якщо перехід оніма в апелятив відбувається без афіксації, тобто без використання словотворчих засобів, то такий перехід називається деонімізацією. В медицині прикладами такого переходу можуть слугувати наступні власні імена:Panacea - Панацея, древньогрецька богиня (грець. Panakeia). IIÏ власне ім'я перейшло в загальне слово panacea - панацея, універсальні ліки; вживалося також як старовинна назва цілющих трав або їхнього соку. Asclepios (Aesculapius) - древньогрецький бог медицини Асклепій, Ескулап. В наш час загальне слово ескулап вживається як жартівлива назва лікаря; загальне слово asclepion (мн. asclepia) має значення асклепіон - один із ранніх грецьких храмів для лікування; Hygiene древньогрецька богиня здоров'я Гігієя, донька Асклепія. В наш час слово hygiene широко вживається в значенні гігієна - наука про здоров'я та його збереження. Narcissus - персонаж древньогрецької міфології, який закохався у власне відображення у воді. Нариис як загальне слово означає самозакохану людину. Hypnosis - грецький бог сну (гр.: жvos), загальне слово hypnosis гіпноз, стан зміненої свідомості, звичайно викликаний штучно. Syphilus - пастух, заражений хворобою у вірші поета Джиролама Фракасторіуса (1530 р) «Сифиліс, або Про галльську хворобу»; загальне слово syphilis сифіліс - хронічна венерична хвороба. Charles Condonвинахідник контрацептиву, спотворена форма від його прізвища condom широко вживається в значенні «презерватив».
Під час трансформації власних імен в загальні слова забуваються і онім і епонім. Причиною забування i власного імені і вихідного епоніму стає те, що епонім втрачає свою функцію індивідуалізації предмету. Ніхто не стане шукати зв'язок загальних слів venereal diseases - венеричні хвороби, venereology -венерологія, venereal dispensary - вендиспансер 3 ім'ям римської богині любові та краси Венери. В загальновживаній мові не кожен пам'ятає про відкриття німецьким вченим В.К. Рентгеном (Wilhelm Konrad Rontgen) радіоактивного випромінювання (1895 р.) коли використовують терміни roentgenograph рентгенограма, roentgenology - рентгенологія, roentgenologist - рентгенолог, назву одиниці випромінювання roentgen - рентген та ще багато термінів, що відносяться до медичного обладнання та медичних обстежень пацієнтів. В медичній термінології англійської мови можуть переходити в загальні слова епонімічні терміни, що складаються з одного власного імені. Перехід медичних епонімів, що складаються 3 двох і більше власних імен або коли власне ім'я вживається у присвійному відмінку $є$ просто неможливим. Спостерігається перехід деяких топонімічних медичних термінів в загальні слова. Tермін Ebola virus отримав свою назву відповідно до місця (Демократична республіка Конго на річці Ебола), де він був вперше виділений в 1976 році. 32002 року він був перейменований в ebolavirus (написання разом і 3 маленької літери). Зараз називається Zaire ebolavirus. При трансформації власних імен в загальні слова останні можуть: - означати явища. Найчастіше для цього вживається суфікс-ism

daltonism - термін, який використовують для позначення порушенного сприйняття червоного i зеленого кольорів; явище, назване на честь вченого Джона Дальтона (John Dalton, 1766-1844);

mongolism - від власного найменування Mongol, застаріле позначення синдрому Дауна;

darvinism - теорія еволюції, згідно 3 якою вищі організми розвиваються 3 нижчих шляхом природного відбору, походить від власного імені Charles Robert Darwin - англійський біолог;

hypnotism - гіпнотизм, дослідження, метод чи практика введення в гіпноз;

narcissism - самозакоханість, самозамилування;

- називати галузь науки. Такі загальні слова утворюються частіше всього за допомогою суфіксу ology:

venereology (венерологія - галузь медицини, що вивчає захворювання, які передаються статевим шляхом) походить від імені богині Венери (лат venus, род. відм.. veneris «плотська любов»);

tanatolohia (система поглядів на причини смерті) походить від власного імені Tanatos - бога, який уособлював смерть;

- утворювати означення. В таких випадках вживаються суфікси -ian, -al, -ic:

parkinsonian facies - паркінсона обличчя незворушний маскоподібний вираз обличчя 3 нечастим кліпанням, патогномонічний для паркінсонізму;

parkinsonian syndrome - Паркінсона синдром;

\footnotetext{
${ }^{7}$ Kalmazova N.A. Specifika medicinskih otonimicheskih terminov v anglijskom jazyke [Specificity of Medical Terms Formed from Proper Names in the English Language], P. 36, URL: https:/www.dissercat.com/content/spetsifika-meditsinskikh-otonimicheskikh- terminov-v-angliiskom-yazyke

${ }^{8}$ Superanskaja A.V. Apelljativ - onoma [ Onomastic Appellative], Imja naricatel'noe i sobstvennoe, M.: Nauka, 1978, P. 36.
} 
venereal disease - венерична хвороба;

aesculapian - такий, що стосується бога медицина або мистецтва медицини;

narcissistic - самозакоханий, такий, що стосується нарцисизму чи характеризується ним;

hypnotic - гіпнотичний; такий, що стосується природи гіпнозу або гіпнотизму; речовина, здатна викликати сон

somnífic - снодійний засіб;

- давати характеристику людей:

Down - загальновживане слово Down означає «людина з вродженою патологією - синдромом Дауна». John Down - англ. лікар (1828 - 1896) вперше описав в 1866 р. симптоми хвороби, яка була названа на його честь Down syndrome or Down disease.

- означати інструменти:

kocher - кохер, скорочення від Kocher's forcepts щипці Кохера, вживається

як сленгове слово хірургами - бути частиною складного слова:

hypnogenesis - гіпногенез, hypnotherapy гіпнотерапія, використання гіпнозу при лікуванні захворювання; латинський еквівалент слова Hipnosis Somnus. Somn $(i)$ стало частиною складних слів, що вказує на відношення до сну: somnilocuism - розмова у ві сні, somnolence - сонливість, дрімота або сон, особливо надмірні;

- означати професію, такі слова утворюються за допомогою суфікса -ist: hypnotist - гіпнотизер - той хто викликає гіпноз;

- утворювати дієслово. Для утворення дієслова вживається суфікс -ize:

to hypnotize - гіпнотизувати, вводити в стан гіпнозу;

to kocherise - операційна технологія розрізання дванадцятипалої кишки при виразках. Термін походить від імені Еміля Теодора Кохера - швейцарського хірурга (1841-1917), який присвятив своє життя дослідженням в галузі фізіології.

- утворювати віддієслівний іменник за допомогою суфікса -ion: hypnotization - гіпнотизування викликання гіпнозу.

Загальні слова на відміну від власних мають i граматичні відмінності. Граматичні відмінності власних імен і загальних слів пов'язані категорією числа. Власні імена можуть мати форму тільки однини. Загальні слова можуть утворювати форми як однини так і множини (condom - condoms, hypnotist - hypnotists); можуть мати при собі означення postencephalitic parkinsonism постенцефалітичний паркінсонізм ; syphilis: cardiovascular - кардіоваскулярний сифіліс; cerebrospinal - цереброспінальний сифіліс; congenital - вроджений сифіліс; primary - первинний, ранній сифіліс; secondary - вторинний сифіліс; tertiary третинний сифіліс; hygiene - може мати при собі означення dental, industrial, radiation.

У фармакології також дуже часто власне ім'я стає загальним словом для позначення якогось класу схожих об'єктів. Такий процес в галузі фармакології може відбуватися 3 назвами торгових марок. Це явище трапляється через декілька об'єктивних причин: відсутність такого товару до появи товару цієї марки; якщо такого товару немає у іншого виробника і якщо в мові немає слова для позначення цього товару. Перехід власної назви товару у загальне слово має свої позитивні та негативні наслідки. Прикладами такого переходу власного імені в загальне слово можуть бути назви ліків, які втратили свої права ексклюзивної власної назви: Vermox - вермокс, торгова марка препарату мебендазолу; Claritin - кларитин, торгова марка препарату лоратадину; Pima - піма, торгова марка препарату йодиду калію.

Висновки і перспективи подальшого дослідження. Епоніми постійно привертають увагу лінгвістів для вивчення їх походження, значення, вживання в різних галузях науки. Хоча існує багато таких вчених, які пропонують вилучити епонімічні терміни з галузі медицини, епоніми широко вживаються для позначення нових явищ в медицині, особливо в країнах, які $є$ ведучими в галузі медичних досліджень, що є доказом розвитку сучасної медицини. На даному етапі у дослідників залишається багато підстав для дискусії відносно спільних рис та розбіжностей між значеннями власних і загальних імен. Це відкриває перспективи подальших досліджень щодо вживання та класифікації епонімічних термінів в галузі медицини.

Shalajeva Anna, Semenko Iryna, Tomka Inna. Transformation of Eponyms in the Field of Medicine into Common Words. The actuality of this article is due to the widespread attention to the use of eponymous terms in the field of medicine. Medical language is a specific language. Substantial part of the medical terminology is presented by eponymical terms. Most often they are used to indicate the disease after the name of the doctor who first described the condition of the sick person or the disease named after a man who suffered from this disease. If eponym refers to the disease, it is often used to describe a symptom, syndrome, factor, test, abnormalities, which are given the name in honour of the doctor-inventor. Most eponyms do not arise as a result of the scientific analysis, research or interpersonal communication. Eponymic terms appear in those areas of medicine where scientific research is often preceded by practical work, thus the eponyms are the result of practical activities of physicians.

In medical terminology the process of converting of personal names into common names often takes place. In this process the proper name loses a number of characteristic properties in the language that become inessential, and is used as a common name. In the field of medicine after the transformation of personal names into common words the latter may: indicate events; give name to a branch of science; form definition; give a description of people; mean instruments; be a part of a compound word; indicate the profession; form a verb or verbal noun.

Eponyms always attracted attention of linguists for studying of their origin, meaning, use in various fields of science. Although there are a lot of scientists who propose to remove eponymic terms from the field of medicine, eponyms are widely used to indicate new notions in medicine, particularly in the countries that are leading ones in the field of medical research, and that is the proof of the development of modern medicine.

The aim of this study is to determine the reasons for the wide use of eponymous terms in the sublanguage of medicine, to study the specificity of medical eponymous terminology, to reveal various points of view on the relationship between the conventional medical terms and eponymous terms, to analyze the differences of medical eponyms and commonly used terminological units, to identify the areas of use of eponymous terminological vocabulary and to investigate the transformation of eponymous terms into

\footnotetext{
${ }^{9}$ Slovar' jeponimicheskih nazvanij boleznej i sindromov. Ortopedija i travmatologija [A Dictionary of Eponymic Names of Diseases and Syndromes . Orthopedics and Traumatology], Rukovoditel' avt. kol. prof. d-r med. nauk Mezhenina E.P., Kiev: Vishha shkola, 1982, P. 45, URL: https://medforo.ru/a/1870/
}

${ }^{10}$ Dorland's Illustrated Medical Dictionary, 29 th edition, 2000, P. 247. 
common nouns may be connected with their use and further development of the classification of common nouns derived from the eponymous terms.

Key-words: personal names, common words, eponymic terms, medicine, transformation.

Шалаєва Анна - стариий викладач кафедри іноземних мов ВДНЗ Украӥни «Буковинський державний медичний університет», Чернівиі (Україна). Автор бере участь у виконанні НДР кафедри, виступае з доповідями на викладацьких конференціях БДМУ, друкує наукові статті в міжнародних та вітчизняних журналах, співавтор граматичних, лексичних посібників для студентів та національного підручника з англійської мови за професійним спрямуванням для медичних психологів.

Shalajeva Anna-senior lecturer of the department of foreign languages of Higher State Educational Establishment of Ukraine „Bukovinian State Medical University“, Chernivtsi (Ukraine). The author takes part in writing of the scientific research works of the department, prepares reports for teachers' conferences of $B S M U$, her articles are published in home and international journals, she is one of the authors of the grammar, lexical manuals for students and the national text-book for medical psychologists.

Семенко Ірина - стариий викладач кафедри іноземних мов ВДНЗ Украйни "Буковинський державний медичний університет", Чернівиі (Украӥна). Автор бере участь у написанні НДР кафедри, виступае з доповідями на конференціях професорсько - викладацького персоналу БДМУ, друкує наукові статті в міжнародних та вітчизняних журналах, співавтор посібників з читання "АВС 1 або Економіка англійською" та "АВС 2. Тестові завдання з читання". Цікавиться проведенням інтегрованих занять та заходів з іноземних мов, математики та економіки.

Semenko Irina - senior lecturer of the department of foreign languages of Higher State Educational Establishment of Ukraine "Bukovinian State Medical University", Chernivtsy (Ukraine). The author takes part in writing of the scientific research works of the department, prepares reports for teachers' conferences of BSMU. Her articles are published in national and international journals, and she is one of the authors of manuals in reading "ABC 1 or Economics in English" and "ABC 2. Tests in reading." She is interested in conducting integrated lessons and activities in foreign languages, mathematics and economics.

Томка Інна - старший викладач кафедри іноземних мов ВДНЗ Украйни «Буковинський державний медичний університет», Чернівиі (Україна). Автор бере участь у виконанні НДР кафедри, виступає з доповідями на викладачьких конферениіях БДМУ, друкує наукові статті в міжнародних та вітчизняних журналах.

Tomka Inna - senior lecturer of the department of foreign languages of Higher State Educational Establishment of Ukraine „Bukovinian State Medical University“, Chernivtsi (Ukraine). The author takes part in writing of the scientific research works of the department, prepares reports for teachers' conferences of BSMU, her articles are published in home and international journals.

Received: 08-01-2017

Advance Access Published: April, 2017

(C) A. Shalajeva, I. Semenko, I. Tomka, 2017 